\title{
Islands with Zero Net Carbon Footprint due to Electricity Use. The Case of Crete, Greece
}

\author{
John Vourdoubas
}

\section{ABSTRACT}

European islands are pioneers in the development of renewable energy technologies. Aim of the current research is to investigate the possibility of zeroing the net annual carbon emissions due to electricity generation in the island of Crete, Greece. Crete, with population 634,930 permanent residents, has abundant solar and wind energy resources while electricity generation from solar-PV systems and wind farms is highly profitable. The electric grid of Crete was autonomous so far but currently its interconnection with the grid of continental Greece is under construction. This will allow soon the transfer of large amounts of electricity between Crete and the mainland. When excess electricity will be generated by solar and wind energy systems in the island it could be transferred in mainland and vice-versa. Carbon neutrality due to electricity generation in Crete can be achieved with local generation of "green solar and wind electricity" combined with electricity transfer via two electric cables with the mainland. Annual electricity generation in Crete is currently at 3,043 GWh while $21.22 \%$ of it is generated by renewable energies. Carbon emissions due to electricity generation are calculated at 3.22 tnCO2/capita. It has been estimated that the required size of solar-PV systems generating annually the electricity currently produced by fossil fuels in Crete is at $1,698 \mathrm{MWp}$ while their cost is at $2.04 \mathrm{bil}$. $€$. The required size of wind farms generating annually the electricity currently produced by fossil fuels is at 950.6 MWel while their cost is at 0.914 bil. $€$. It is concluded that carbon neutrality due to electricity generation in Crete is technically and economically feasible.

Keywords: Crete-Greece, electricity, islands, renewable energies, zero carbon footprint.

Published Online: February 23, 2021

ISSN: $2684-446 \mathrm{X}$

DOI : $10.24018 /$ ejgeo.2021.2.1.116

John Vourdoubas*

Consultant Engineer, Greece.

(e-mail: vourhome ${ }^{\circledR}$ otenet.gr)

*Corresponding Author

\section{INTRODUCTION}

Global efforts for mitigation of climate change require the urgent replacement of fossil fuels with renewable energies. Current advances in various renewable energy technologies have increased their reliability and decreased their cost allowing their use in many applications. Mediterranean region is characterized by abundant indigenous solar and wind energy resources which could be used in electricity, heat and cooling generation. Island of Crete, Greece is located in south east Mediterranean basin and it consists of a popular tourist destination. Its electric grid was autonomous while currently its interconnection with the continental grid of Greece is under development. Although Crete is rich in solar and wind energy resources electricity is mainly generated by thermal power plants using fuel oil and diesel oil. Approximately only $20 \%$ of its annual electricity consumption is generated by renewable energies (REs) mainly with solar photovoltaic (solar-PV) and wind energy. Our work investigates the possibility of zeroing Crete's net carbon emissions due to electricity use taking into account that its electric grid will be soon interconnected with the grid of continental Greece. This can be achieved with the use of solar-PV systems and wind farms for electricity generation taking into account the cost-efficiency of these technologies and the abundance of solar and wind energy resources in the island. Current research is important since it indicates the way to increase the use of REs in energy generation reducing the carbon emissions as well as the fossil fuels use in Crete which could be replicable in other islands. It is also important since it contributes to the realization of the European target to zero its carbon footprint and to be transformed in a carbon neutral continent by 2050 .

\section{LITERATURE SURVEY}

\section{A. Use of Renewable Energies in Islands}

Juswanto et al [1] have reviewed the developments in renewable energies in Pacific islands. The authors stated that currently REs including solar and wind energy contribute at around $20 \%$ to $40 \%$ in their energy balance. They also mentioned that by 2030 Cooks islands, Fiji Islands and 
Vanuatu are planning to cover all their annual energy needs with REs. A roadmap for the maximization of the penetration of RES in islands adopting energy storage technologies has been reported [2]. The report stated that electricity storage systems in islands include: a) Electric batteries, b) Pump hydro storage systems, c) Energy storage in $\mathrm{H}_{2}$, and d) water desalinations systems which though are not conventional energy storage systems. Kuang et al [3] have reviewed the renewable energy utilization in islands. The authors stated that REs including solar energy, wind energy, hydro energy, geothermal energy, ocean energy and biomass can be used, when available, for energy generation in islands. They also mentioned that advanced technologies facilitate their deployment including energy storage, hybrid energy systems, micro-grids and smart grids, distributed generation and demand-side management. Ali et al [4] have modeled a hybrid renewable energy system for a small remote island located in South Korea. The authors used a hybrid solar-PV and wind turbine system generating on the average $24,720 \mathrm{KWh}$ daily covering all the energy needs in the island. They also studied two electricity storage systems including electric batteries and pump hydro storage. IRENA [5] has reported on worldwide applications of REs in islands. The report described various case studies related with the use of REs for electricity generation in different islands all over the world. Use of REs in European islands has been reported [6]. The report mentioned the Danish concept of islands covering all their energy requirements with REs with reference the island of Samso. It contains various case studies regarding utilization of REs in EU islands focusing in organizational and technical issues as well as in local aspects regarding the availability and use of REs.

\section{B. Zero Carbon Emissions Island}

Lido is a Swedish zero carbon island [7]. Eighteen different technological solutions have been used based on various REs including the use of biodiesel in transportation. The concept of zero carbon vacations has been also promoted to island's visitors. A network of Nordic islands has been established with ambitions to become carbon neutral [8]. More than sixty (60) technologies based on REs have been identified that can be used in these islands to minimize or zero their carbon footprint. Stadthalle boutique hotel at Vienna [9] has annual zero energy balance. The hotel uses only renewable energy technologies, including solar-PV systems, solar thermal systems and groundwater heat pumps, for covering all its annual energy requirements. Palau island [10] is located in Oceania southeast of Philippines and is inhabited by 18,000 residents. This small island is an attractive tourist destination, and it is planning to become the first carbon neutral tourist destination worldwide. Achievement of climate-neutral EU by 2050 has been approved on 12/12/2019 [11] by European Council. According to this decision member states have the right to decide on the preferable energy mix and to choose the most appropriate energy technologies for achieving carbon neutrality by 2050. Marczinkowski et al [12] have investigated the transitioning in island's energy systems towards $100 \%$ RES by 2030 . The authors studied the transitioning in three European islands, Samso, Orkney and
Madeira towards energy self-sufficiency with $100 \%$ REs. They stated that there is a variety of energy systems and solutions depending on local conditions, development phases as well as the local availability of various REs regarding the island's transition towards $100 \%$ REs. Marczinkowski et al [13] have studied the transition of Madeira island to $100 \%$ renewable energy system. The authors examined two different energy approaches using the energy PLAN modeling tool. They mentioned that with lack of cross-border trading a complex energy system and use of smart technologies are required to improve island's selfsufficiency in energy. A Mediterranean energy transition plan for 2040 has been developed [14] Compared with the "business-as-usual" scenario the proposed Mediterranean transition scenario would lead in: a) $30 \%$ reduction in energy demand, b) increased share of REs at $27 \%$ of the energy mix in the region with REs becoming the primary source of electricity generation, and c) reduction in $\mathrm{CO}_{2}$ emissions by $38 \%$. Dominkovic et al [15] have proposed a zero carbon energy system for South East European countries in 2050. The authors stated that there are large differences in energy mixes in these countries and many different technologies should be used to zero their carbon footprint. They suggested the use of various benign energy technologies including solar-PVs, wind turbines, geothermal and solar thermal systems, hydro power, co-generation of heat and power (CHP) driven on biomass as well as synthetic fuel technologies.

\section{Electricity Storage and $\mathrm{H}_{2}$}

Nikolaou et al [16] have studied the storage of electricity rejected from wind parks in the island of Crete, Greece in hydro pump storage systems. The authors mentioned the "Potamon" dam located in Rethymno prefecture which could be used for storing excess electricity. They stated that the optimum size of power generating turbines should be at $31 \mathrm{MW}_{\mathrm{el}}$ while the annually generated electricity is estimated at $2-2.2 \%$ of island's annual electricity consumption. Salameh [17] has studied the viability of $\mathrm{H}_{2}$ economy in Iceland. The author mentioned that Iceland has abundant renewable energy sources (RES) like hydropower and geothermal energy resources which can be used for $\mathrm{H}_{2}$ production in a cost efficient way. He also stated that Norway and Canada meet the criteria for a successful $\mathrm{H}_{2}$ economy. However other countries cannot achieve that without the massive use of fossil fuels which is not desirable. Pina et al [18] have studied the use of electric vehicles in small, isolated islands with reference Flores island Azores, Portugal. The authors stated that electric vehicles can be used for energy storage and sustainable mobility. However, they mentioned, electric vehicles are going to be competitive only when fuel prices will be significantly increased. Chen et al [19] have studied the integration of REs with $\mathrm{H}_{2}$ production and utilization with fuel cells in European islands. The authors stated that promotion of intermittent REs in islands requires their integration with electrolytic $\mathrm{H}_{2}$ production and utilization with FCs. Use of REs for $\mathrm{H}_{2}$ production allows storage of electricity while $\mathrm{H}_{2}$ can be used, apart from electricity storage, as fuel in electric vehicles equipped with fuel cells. Rodrigues et al [20] have studied the feasibility of electricity 
storage systems in the island of Terceira, Azores, Portugal. The authors mentioned that the installed power in the island in 2012 was at $75.1 \mathrm{MW}$ while the maximum electricity demand in 2018 would be around $30 \mathrm{MW}$ to $35 \mathrm{MW}$. They estimated the optimum size of an electricity storage system for 2018 at $8.1 \mathrm{MW}$ generated from water turbines operating in static waterfall at $340 \mathrm{~m}$ and a water flow rate at 3 $\mathrm{M}^{3} / \mathrm{sec}$. They also compared electric batteries with hydro pump storage. The estimated cost of a hydro pump storage system at 8.1 MW was 15.56 mil $€$ while of batteries 28.27 mil. $€$.

\section{Island of Crete and Aegean Sea Islands}

Chatziargiriou et al [21] have studied the renewable energy developments in Greek islands. The authors stated that Greek comprises 124 inhabited islands in which renewable energy sources (RES) can be used as a test bed for their economic development. They also mentioned that deployment of RES in these islands could provide an additional income to local residents while islands offer the opportunity for development of innovative RES systems integrating electricity storage. Electricity generation and fossil fuel consumption in Crete in 2018 has been reported by DEDDIE [22]. Total electricity generation in Crete during 2018 was at 3,042,806 MWh while most of it was generated in thermal power stations fueled by heating oil and diesel oil. The share of REs in electricity generation was slightly higher than $20 \%$. Vourdoubas [23] has studied the use of REs in rural areas in the island of Crete. The author stated that solar energy, wind energy, hydro energy, biomass and low enthalpy geothermal energy are already used in Crete. He also mentioned that currently REs generate more than $20 \%$ of island's electricity consumption while their share is expected to increase in the near future. Gigantidou [24] has studied the use of REs for electricity generation in Crete. The author stated that the growth of wind farms and solar-PV systems in Crete is almost similar with the growth reported in Spain and Germany. Management of these benign energy systems offers new knowledge and experience for their optimum penetration in the island's electric grid. Tzanes et al [25] have studied the electricity generation status for non-interconnected islands in Aegean Sea excluding the islands of Crete and Rhodos. The authors stated that due to existing technical limitations the annual share of REs in the energy mix has been stagnated at around $15 \%$ to $18 \%$. They also mentioned that the cost of electricity generation with thermal power stations in small islands is very high at around $600 € / \mathrm{MWh}$. They proposed the development of electricity storage systems in order to increase the penetration of REs in the energy mix in these islands. Tsekeris [26] has investigated the energy transition of the Greek non-interconnected islands. The author stated that specific transition policies have to be developed. He also mentioned that the national targets for 2030 include a $32 \%$ penetration of REs in the energy mix as well as a $40 \%$ reduction in $\mathrm{CO}_{2}$ emissions. Regarding the transportation sector it is foreseen a total transformation of the fuel mix used and the increasing use of electric vehicles and trains. Biza et al [27] have studied the interconnection of the electric grids of Crete and continental Greece. The authors stated that the interconnection will take place in two phases.
In phase 1 the electric grid of Crete will be interconnected with Peloponnese's grid with transferring capacity at 150 MW to $180 \mathrm{MW}$. In phase 2 the electric grid of Crete will be interconnected with Attica's grid with transferring capacity at $350 \mathrm{MW}$. Vourdoubas [28] has investigated the possibility of creating net zero carbon emissions residential buildings in Crete, Greece. The author stated that all the energy requirements in residential buildings in Crete can be covered with locally available REs zeroing their net carbon footprint due to energy use. He also mentioned that carbon neutrality can be achieved with the use of solar thermal energy, solar-PV energy and high efficiency heat pumps. Katsaprakakis et al [29] have studied the energy independency in the island of Crete. The authors mentioned that despite the interconnection of the electric grids of Crete and continental Greece the creation of pump hydroelectricity storage systems in the island could increase the use of REs in power generation. They have searched the island for finding favorable locations for installing pump hydro storage systems and they have identified fourteen sites. An announcement on TILOS project aiming to maximize the use of REs in covering the electricity needs of Tilos island, Greece has been made [30]. A new prototype hybrid system for electricity generation and storage is going to be developed in this island. It will be consisted of a wind turbine at $800 \mathrm{KW}$, a small scale solar-PV system at 160 $\mathrm{KW}_{\mathrm{p}}$ and a battery storage system at 2.4 MWh.

Aims of the current research are:

a) The mapping of the electricity generation system in Crete,

b) The estimation of the share of REs in the energy mix as well as the island's carbon emissions related with electricity generation, and

c) The estimation of the size and the cost of the RE systems that are required for achieving zero annual net carbon emissions in Crete due to electricity generation.

Following the literature survey, the electricity generation system in Crete is described as well as the aspects of the interconnection of the electric grids of Crete and continental Greece. After that the possibility of electricity storage in the island is mentioned and the $\mathrm{CO}_{2}$ emissions due to fossil fuels use in electricity generation are calculated. In the next section the requirements for net zero $\mathrm{CO}_{2}$ emissions due to electricity use in Crete are stated while the required size and cost of the solar-PV systems and wind farms generating the same amount of electricity that is currently generated by fossil fuels in the island are estimated. In the remaining sections the discussion of the findings and the conclusions drawn are mentioned.

\section{THE ELECTRICITY GENERATION SYSTEM OF CRETE}

\section{A. Electricity Generation}

Electricity is generated in Crete with fossil fuels and renewable energies. Three thermal power stations operate currently in Crete using fuel oil and diesel oil generating approximately $80 \%$ of the annual electricity in the island. The remaining $20 \%$ is generated by renewable energies mainly by solar-PV systems and wind parks. There are also 
two tiny hydro power stations and three tiny biogas power stations operating in Crete. However, their share in the electricity mix in Crete is negligible. The electric grid in Crete was so far autonomous but its interconnection with the electric grid of continental Greece with two undersea electric cables is under implementation and it is expected that it will be finalized by the next two years. Island of Crete has abundant solar and wind energy resources, and the generation of solar and wind electricity is cost-efficient. Many investors are interesting to install solar-PV systems and wind parks for electricity generation. However, this was not allowed so far for grid stability reasons taking into account that the island's electric grid was autonomous. Apart from solar and wind energy Crete has a lot of solid biomass resources based on the extensive olive tree cultivation in the island. Hydro energy and high enthalpy geothermal energy resources are limited in Crete. It is expected that in the near future a solar thermal power plant will be created in Crete as well as various offshore wind farms. It is foreseen that generation of green electricity based on REs in Crete will be increased after the interconnection of its electric grid. Electricity generation and carbon emissions in Crete from various fossil fuels and energy sources are presented in table 1 while their installed capacities are presented in Table 1.

TABLE 1: ELECTRICITY GENERATION AND CARBON EMISSIONS IN CRETE FROM VARIOUS FOSSIL FUELS AND ENERGY SOURCES $(2018)^{1,2}$

\begin{tabular}{|c|c|c|c|c|c|}
\hline Fuel & $\begin{array}{l}\text { Annual fuel } \\
\text { consumption } \\
\text { (tons) }\end{array}$ & $\begin{array}{l}\text { Annual } \\
\text { electricity } \\
\text { generation } \\
(\mathrm{MWh})\end{array}$ & $\%$ & $\begin{array}{l}\text { Annual } \\
\mathrm{CO}_{2} \\
\text { emissions } \\
\text { (tons) }\end{array}$ & $\%$ \\
\hline Fuel oil & 455,684 & $1,762,612$ & 57.91 & $1,435,405$ & 70.30 \\
\hline Diesel oil & 195,055 & 635,070 & 20.87 & 606,621 & 29.70 \\
\hline $\begin{array}{c}\text { Total } \\
\text { fossil fuels }\end{array}$ & 650,739 & $2,397,682$ & 78.78 & $2,042,026$ & 100 \\
\hline $\begin{array}{c}\text { Solar } \\
\text { energy }\end{array}$ & 0 & 134,808 & 4.43 & 0 & 0 \\
\hline $\begin{array}{l}\text { Wind } \\
\text { energy }\end{array}$ & 0 & 510,059 & 16.76 & 0 & 0 \\
\hline $\begin{array}{l}\text { Hydro } \\
\text { electric } \\
\text { energy }\end{array}$ & 0 & 257 & 0 & 0 & 0 \\
\hline $\begin{array}{c}\text { Total } \\
\text { renewable } \\
\text { energies }\end{array}$ & 0 & 645,124 & 21.22 & 0 & 0 \\
\hline Total & 650,739 & $3,042,806$ & 100 & $2,042,026$ & 100 \\
\hline
\end{tabular}

${ }^{1}$ Small quantities of electricity generated from biogas are not included.

2 Carbon emission coefficients for electricity generation $=0.67$ $\mathrm{kgCO}_{2} / \mathrm{KWh}$.

\section{B. Productivity of Existing Renewable Energy Systems in Crete}

The productivity of the solar-PV systems and the wind parks currently operating in Crete are estimated from existing data regarding the installed power and the electricity generation for 2018 which are presented in Table 2. The annual productivity of the solar-PV systems is at $1,412 \mathrm{MWh} / \mathrm{MW}_{\mathrm{p}}$ while the capacity factor for the wind parks is at 0.291 .
TABLE 2: INSTALLED CAPACITY OF POWER STATIONS AND EFFICIENCY OF SOLAR-PV SYSTEMS AND WIND PARKS USED IN CRETE FOR ELECTRICITY GENERATION (2018)

\begin{tabular}{cccc}
\hline $\begin{array}{c}\text { Energy } \\
\text { source/Technology }\end{array}$ & $\begin{array}{c}\text { Installed } \\
\text { capacity }\end{array}$ & $\begin{array}{c}\text { Annual electricity } \\
\text { generation } \\
(\mathrm{MWh})\end{array}$ & $\begin{array}{c}\text { Annual } \\
\text { productivity/ } \\
\text { capacity factor }\end{array}$ \\
\hline Solar photovoltaic & $95.5 \mathrm{MW}_{\mathrm{p}}$ & 134,808 & $\begin{array}{c}\text { Annual } \\
\text { productivity= } \\
1,412 \\
\text { MWh/MW }\end{array}$ \\
Wind parks & 200.3 & 510,059 & $\begin{array}{c}\text { Capacity factor } \\
=0.291\end{array}$ \\
Hydro electric & $0.6 \mathrm{MW}_{\mathrm{el}}$ & 256.8 & \\
Total renewable & 296.4 & & \\
energies & $\mathrm{MW}_{\mathrm{el}}$ & 644,867 & \\
Thermo-electric & 824.6 & & \\
power & $\mathrm{MW}_{\mathrm{el}}$ & $2,978,318$ & \\
Total & $1,120.1$ & $3,042,805$ & \\
$\mathrm{MW}_{\mathrm{el}}$ & & & \\
\hline
\end{tabular}

Source: HEDNO, 2018, Own estimations.

\section{INTERCONNECTION OF THE ELECTRIC GRID IN CRETE WITH THE CONTINENTAL ELECTRIC GRID}

The electric grid of Crete was until recently autonomous. During the previous years the interconnection of the island's grid with the electric grid of the mainland was planned with two undersea electric cables despite the technical difficulties of the project. One cable is able to transfer 150-180 MW and the other $350 \mathrm{MW}$. The implementation of the smaller cable was finalized in the end of 2020 while the finalization of the second is foreseen by 2023. During the past when Crete's electric grid was autonomous there were limitations, due to grid stability reasons, regarding the maximum installed power of intermittent renewable energy systems including solar-PV and wind generated electricity. Hydro pump storage systems for electricity storage in Crete have not been constructed so far although existing studies have indicated their technical and economic feasibility. Due to these restrictions the current contribution of REs in the local energy mix is only slightly higher than $20 \%$. The current electricity cost also in Crete is very high, at around 500-600 $€ / \mathrm{MWh}$, due to the operation of small and inefficient thermal power stations. The solar and wind potential in Crete is high and the solar and wind electricity generation technologies are mature and profitable. However, energy investments in solar-PV systems and wind farms were far below the capacity of the island although investors were interested to realize these projects. It is expected that soon the polluting and cost inefficient thermal power stations will stop their operation in Crete while more wind farms and solar electricity generation systems will be deployed.

\section{EleCtricity StORAGE IN CRETE}

Electricity can be stored in various systems including electric batteries, hydrogen, and hydro pump storage (HPS) systems. Electric batteries can store small quantities of electricity although current advances in their technology allow the use of large capacity batteries storing many MWh. Future electricity storage in large batteries is foreseen when their cost will be attractive. Additionally, it can be stored in the batteries of electric vehicles promoting V2G solutions. 
Pump hydro storage systems are more favorable for the size of the Crete's electric grid while due to the geomorphology of the island many sites can be identified and used for the creation of electricity storage systems. Currently pump hydro storage systems are the best option for electricity storage in Crete taking into account technical and economic criteria while their deployment will increase island's energy security. Use of $\mathrm{H}_{2}$ for electricity storage is not currently indicated due to economic and technical reasons. However, it remains an attractive future option for Crete when the transition to a hydrogen economy will become a necessity. Sustainable energy technologies that can be used for electricity storage in Crete are presented in Table 3.

TABLE 3: SUSTAINABLE ENERGY TECHNOLOGIES THAT CAN BE USED IN

\begin{tabular}{ccc}
\multicolumn{2}{c}{ CRETE FOR ELECTRICITY STORAGE } \\
\hline Energy Technology & Energy stored & Current use in Crete \\
\hline Electric batteries & Chemical energy & Yes \\
Hydro pump storage & Hydro energy & No (it is planned) \\
systems & Chemical energy & No \\
Hydrogen & Con
\end{tabular}

\section{CARBON EMISSIONS DUE TO ELECTRICITY GENERATION IN CRETE}

$\mathrm{CO}_{2}$ emissions due to electricity generation by fossil fuels are estimated at 2,042,026 $\mathrm{tnCO}_{2}$ in 2018 (Table 1). Taking into account that the permanent residents in the island are 634,930, $\mathrm{CO}_{2}$ emissions per capita due to electricity generation are calculated at $3.22 \mathrm{tnCO}_{2}$. According to World Bank [31] $\mathrm{CO}_{2}$ emissions in Greece, in 2016, were 5.8 $\mathrm{tnCO}_{2}$ per capita. Therefore, the $\mathrm{CO}_{2}$ emissions due to electricity generation in Crete are higher than $50 \%$ of the overall $\mathrm{CO}_{2}$ emissions in the island.

\section{REQUIREMENTS FOR NET ZERO CARBON EMISSIONS DUE TO ELECTRICITY GENERATION IN CRETE}

The interconnection of the electric grids of Crete and continental Greece allows the transfer of electricity through the two undersea cables. This results in significant decrease of the electricity generation cost in Crete with the existing thermal power stations since low cost electricity can be transferred to the island. The electric cables offer the opportunity for power generation from the abundant REs in Crete preferably from solar and wind energy assisting in decarbonization of power generation. When excess green electricity will be generated in Crete it will transferred to continental Greece. Vice-versa when the electricity generated in Crete is lower than the power demand electricity will be transferred via the cables. Therefore, the inter-connection of the electric grids facilitates the decarbonization of the island. In order to zero the net carbon emissions due to electricity generation in Crete the following conditions should be fulfilled:

A) Use of fossil fuels in electricity generation in the island should be minimized while the use of REs should be promoted,

B) Since electricity generated by fossil fuels in continental Greece will be transferred to Crete through the two undersea electric cables the same amount of "green electricity" generated in Crete by REs should be transferred back annually, and

C) Any remaining carbon emissions due to fossil fuels use for power generation in Crete should be annually offset by carbon sequestration from tree plantations which should be created in Crete.

Renewable energy technologies which are currently used or could be used in the future for electricity generation in Crete are presented in Table 4. They include utilization of solar energy, wind energy, hydroelectric energy and biomass.

TABLE 4: SustainABLE ENERGY TECHNOLOGIES THAT CAN BE USED IN CRETE FOR ELECTRICITY GENERATION

\begin{tabular}{|c|c|c|}
\hline Energy source & Technology & $\begin{array}{l}\text { Current use in } \\
\text { Crete }\end{array}$ \\
\hline Solar energy & Photovoltaic cells & Yes \\
\hline Solar energy & $\begin{array}{l}\text { Solar thermal power } \\
\text { systems with parabolic } \\
\text { troughs }\end{array}$ & No (it is planned) \\
\hline Wind power (on-shore) & Wind turbines & Yes \\
\hline Wind power (off-shore) & Wind turbines & No \\
\hline Biogas & Burning & Yes \\
\hline Solid biomass & Burning & No \\
\hline Hydro energy & Hydro turbines & Yes \\
\hline Electrolytic hydrogen & Fuel cells & No \\
\hline
\end{tabular}

\section{SIZE AND COST OF RENEWABLE ENERGY TECHNOLOGIES FOR ACHIEVING NET ZERO CARBON EMISSIONS DUE TO ELECTRICITY GENERATION IN CRETE}

Annual electricity generation by fossil fuels in Crete in 2018 was at 2,397,682 MWh (Table 1). In order to size the solar-PV systems and the wind farms necessary for generating the abovementioned electricity in the island and to estimate their installation cost the following assumptions have been made:

a) The annual productivity of the solar-PV systems in Crete is $1,412 \mathrm{MWh} / \mathrm{MW}_{\mathrm{p}}$,

b) The capacity factor of the wind farms in Crete is 0.291 ,

c) The unit cost of the solar-PV systems is $1,200 € / \mathrm{KW}_{\mathrm{p}}$,

d) The unit cost of the wind farms is $1,000 € / \mathrm{KW}_{\mathrm{el}}$

The size and the cost of the necessary RE systems are presented in Table 5. In the same table is also presented the investment cost in solar-PV and wind power systems per annual $\mathrm{CO}_{2}$ savings.

TABLE 5: SIZE AND COST OF THE REQUIRED SOLAR-PV AND WIND

ENERGY SYSTEMS GENERATING GREEN ELECTRICITY IN CRETE

\begin{tabular}{ccc}
\multicolumn{2}{c}{ ENERGY SYSTEMS GENERATING GREEN ELECTRICITY IN CRETE } \\
\hline $\begin{array}{c}\text { Electricity generation } \\
\text { (which is currently }\end{array}$ & $2,397,682 \mathrm{MWh}$ & Wind farms \\
produced by fossil & & $2,397,682 \mathrm{MWh}$ \\
fuels) & $1,698 \mathrm{MW}_{\mathrm{p}}$ & $940.6 \mathrm{MW}$ el \\
Size & $2.04 \mathrm{bil} €$ & $0.941 \mathrm{bil} . €$ \\
Cost & $3,213 € /$ capita & $1,482 € / \mathrm{capita}$ \\
Cost per inhabitant ${ }^{1}$ & $1 €$ per kg of annual & $0.46 € \mathrm{per} \mathrm{kg} \mathrm{of}$ \\
Investment cost in RE & $\mathrm{CO}_{2}$ savings & annual $\mathrm{CO}_{2}$ savings \\
systems per annual & $\mathrm{CO}_{2}$ savings &
\end{tabular}

${ }^{1}$ Number of permanent inhabitants in Crete $=634,930$.

\section{DISCUSSION}

The use of indigenous renewable energy resources in islands worldwide has been extensively studied. It has been indicated that using local benign energy sources utilization of fossil fuels in energy generation could be minimized or 
zeroed assisting in the mitigation of climate change. Our results indicate that using the abundant solar and wind energy resources in Crete all the electricity required in the island could be generated in a cost-efficient way while the investment cost in solar and wind energy systems is not prohibitive. Currently the interconnection of the electric grid of Crete with the grid of continental Greece, using two undersea electric cables, is under construction. This will allow soon the transfer of electricity between Crete and continental Greece. The possibility of exchanging annually electricity generated by fossil fuels in continental Greece with "green electricity" generated by solar and wind energy in Crete will allow Crete to achieve its carbon neutrality due to electricity generation. Apart from solar-PV systems and wind parks various other RE technologies can be used in Crete for electricity generation. The geomorphology of the island allows the creation of pump hydroelectricity storage systems [29]. Their construction will increase the energy security in Crete providing electricity into the grid in the case of major failures or emergency cases. It has been indicated [20] that their use in islands for electricity storage is less costly compared with electric batteries. However current advances in electric batteries' technology will probably allow soon their use for storing electricity at an affordable cost. Use of $\mathrm{H}_{2}$ for electricity storage is not currently an attractive option in Crete. Existing studies [28] have indicated the technical and economic viability of residential buildings in Crete to zero their annual carbon footprint due to electricity consumption using small scale solar-PV systems. Existing experience from net zero energy hotels [9] indicate that they could also operate in Crete where tourism is the main industry. Apart from large size solar and wind energy systems electricity can be also generated in Crete by small size solar-PV systems installed in residential buildings and hotels according to net-metering regulations. Our results are important because they indicate that the island of Crete can reduce or zero its $\mathrm{CO}_{2}$ emissions due to energy use complying with the EU target of zeroing all carbon emissions in Europe by 2050. They do not indicate though the economic benefit that will be achieved by replacing the existing, cost-inefficient, thermal power stations in Crete with new solar and wind electricity generation systems.

\section{Conclusions}

The possibility of zeroing the net carbon emissions due to electricity generation in the island of Crete, Greece has been investigated. The interconnection of the electric grid of Crete with the grid of continental Greece is under implementation with two undersea electric cables while the rich solar and wind energy resources in the island allow their use for electricity generation in a cost-efficient way. Carbon neutrality in Crete can be achieved with the exchange, via the electric interconnection, of "green solar and wind generated electricity" in Crete with "fossil fuel based electricity" generated in continental Greece. Total electricity generation in Crete during 2018 was at 3,042,805 MWh while the electricity generated by fossil fuels was at 2,397,682 MWh and the rest was generated by renewable energies. The annual carbon emissions due to electricity generation in Crete have been calculated at $3.22 \mathrm{tnCO}_{2}$ per capita which is slightly higher than $50 \%$ of the annual overall $\mathrm{CO}_{2}$ emissions in the island. The size of the necessary solar-PV plants generating all the electricity currently produced by fossil fuels in Crete is at $1,698 \mathrm{MW}_{\mathrm{p}}$ while their investment cost is at 2.04 bil. $€$. The size of the necessary wind farms generating all the electricity currently produced by fossil fuels in Crete is at $950.6 \mathrm{MW}_{\mathrm{el}}$ while their investment cost is at 0.941 bil. $€$. The investment cost of the abovementioned renewable energy systems varies between $1482 € /$ capita to $3213 € /$ capita while the investment cost per carbon emission savings varies between 0.46-1.00 $€$ per $\mathrm{kg}$ of annual $\mathrm{CO}_{2}$ emission savings. The realization of the interconnection of the electric grids of Crete and continental Greece in the next two years will allow the sharp decrease of the carbon emissions in the island with affordable cost assisting in the compliance with the EU target for carbon neutral continent by 2050. The required investments in benign energy technologies could be realized by private investors or alternatively by energy cooperatives offering the possibility to local residents to participate in climate change mitigation achieving at the same time an economic benefit. Further research should be focused in sizing the necessary pump hydro storage systems in the island for increasing its energy security ensuring adequate electricity supply in emergency cases like failures in the electric cables. It should be also focused on the estimation of the annual economic benefit that will be achieved with the replacement of fuel oil and diesel oil currently used for electricity generation in Crete with solar and wind energy.

\section{REFERENCES}

[1] Juswanto, Wawan \& Ali, Zulfiqur, "Renewable energy and sustainable development in Pacific island countries," in Pacific Update Conference: Inclusive Growth for Enhanced Resilience, University of the South Pacific, Suva, Fiji, 18-19 July, 2016. $\begin{array}{cccc}\text { Retrieved at } & 5 / 2 / 2021 & \text { from }\end{array}$ https://www.adb.org/sites/default/files/publication/215216/adbipb2016-5.pdf.

[2] "Maximization of the penetration of RES in islands, Roadmap" (2010), IEE project.

[3] Kuang, Y., Zhang, Y., Zhou, B., Li, C., Cao, Y., \& Li, L., “A review of renewable energy utilization in islands," Renewable and Sustainable Energy Reviews, vol. 59, pp. 504-513, 2016. http://dx.doi.org/10.1016/j.rser.2016.01.014.

[4] Ali, S., \& Jang, C.M., "Optimum design of a hybrid renewable energy system for sustainable energy supply to a remote island," Sustainability, vol. 12, 1280, 2020. doi: 10.3390/su12031280.

[5] "A path to prosperity: Renewable energy for islands," $3^{\text {rd }}$ edition, Framework Convention on Climate Change, held in Marrakesh, Morocco, 7-18 November, 2016, $22^{\text {nd }}$ session of the Conference of the Parties (COP22) to the United Nations. Retrieved at 5/2/2021 from https://www.irena.org//media/Files/IRENA/Agency/Publication/2016/ IRENA_Path_to_Prosperity_Islands_2016.pdf.

[6] "Renewable Energy Islands in Europe," European seminar on renewable energy islands, Samso island, Denmark, 29-30 June, 1998. $\begin{array}{lll}\text { Retrieved at } & 5 / 2 / 2021 & \text { from }\end{array}$ https://www.osti.gov/etdeweb/servlets/purl/317117.

[7] https://www.livingcircular.veolia.com/en/city/welcome-lido-swedenszero-carbon-island.

[8] https://nordregioprojects.org/carbon-neutral-islands/.

[9] https://www.hotelstadthalle.at/index-en.html.

[10] https://pebblemag.com/magazine/travelling/palau-carbon-neutraldestination.

[11] Long term low greenhouse gas emission development strategy of the EU and its member states, 2020. Retrieved at 5/2/2021 from https://unfccc.int/sites/default/files/resource/HR-03-06 
2020\%20EU\%20Submission\%20on\%20Long\%20term\%20strategy.p df.

[12] Marczinkowski, H.M., Ostergaard, P.A., \& Djorup, S.R., "Transitioning island energy systems - Local conditions, development phases and renewable energy integration," Energies, vol. 12, 3484, 2019. doi:10.3390/en12183484.

[13] Marczinkowski, H.M., \& Barros, L., "Technical approaches and Institutional alignment to $100 \%$ renewable energy system transition of Madeira island - electrification, smart energy and required flexible market conditions," Energies, vol. 13, 4434, 2020. doi:10.3390/en13174434.

[14] Mediterranean Energy Transition: 2040 Scenario, in $4^{\text {th }}$ MEDENER International Conference "Enhancing energy transition in the Mediterranean towards a sustainable energy mix”, 25 May, 2016, Algiers. Retrieved at 4/2/2021 from https://www.ademe.fr/sites/default/files/assets/documents/vers_engl_ 25_oct_bat_web.pdf.

[15] Dominkovic, D.F., Baekovi, I., Osi, B., Krajai, G., Puksec, T., Dui, N., \& Markovska, N., "Zero carbon energy system of South East Europe in 2050," Technical University of Denmark, 2016. Retrieved at 4/2/2021 from http://www.go100re.net/wpcontent/uploads/2014/01/Zero-carbon-energy-system-of-SEE.pdf.

[16] Nikolaou, T., Stavrakakis, G.S., \& Tsamoudalis, K., "Modeling and optimal dimensioning of a pumped hydro energy storage system for the exploitation of the rejected wind energy in the non-interconnected electrical power system of the Crete island, Greece," Energies, vol. 13, 2705, 2020. doi: 10.3390/en13112705.

[17] Salameh, G.M., "How viable is the hydrogen economy? The case of Iceland," International Association for Energy Economics, second quarter, pp. 11-17, 2009.

[18] Pina, A., Ioakimidis, Ch.S., \& Ferrao, P., "Introduction of electric vehicles in an island as a driver to increase renewable energy penetration," ICSET 2008.

[19] Chen, F., Duic, N., Alves, L.M., \& Carvalho, M.D.G., "Renewislands - Renewable energy solutions for islands," Renewable and Sustainable Energy Reviews, vol. 11, pp. 1888- 1902, 2007. doi:10.1016/j.rser.2005.12.009.

[20] Rodrigues, A., Machado, D., \& Dentinho, T., "Electric energy storage systems feasibility; the case of Terceira island," Sustainability, vol. 9, 1276, 2017. doi:10.3390/su9071276.

[21] Chatziargiriou, N., Margaris, I., \& Dimeas, A., "Renewable energy developments in Greek islands, Friedrich Ebert Stiftung," Retrieved at 4/2/2021 from https://library.fes.de/pdf-files/bueros/athen/13050.pdf.

[22] Annual report on the energy system in Crete, (2018), Hellenic Electricity Distribution Network Operator (DEDDIE), (in Greek).

[23] Vourdoubas, J., "Use of renewable energy sources for energy generation in rural areas in the island of Crete, Greece," European Journal of Environment and Earth Sciences, vol. 1(6), pp. 1-7, 2020. DOI: http://dx.doi.org/10.24018/ejgeo.2020.1.6.88.

[24] Gigantidou, A., "Renewable energy sources in Crete," IREP Symposium - Bulk Power System Dynamics and Control. IX (IREP), Rethymno, Crete, Greece, $2013 . \quad$ Available: http://papers.irep2013.ntua.gr/83.pdf.

[25] Tzanes, G., Zafeiraki, E., Papapostolou, Ch., Zafirakis, D. Moustris, K., Kavadias, K., Chalvatzis, K., \& Kaldellis, J.K., "Assessing the status of electricity generation in the non-intercontinental islands in the Aegean sea region," Energy Procedia, vol.159, pp. 424-429, 2019. 10.1016/j.egypro.2018.12.065.

[26] Tsekeris, D. (2019). The energy transition of the Greek noninterconnected islands, Greek Ministry of Environment and Energy. Available: https://hybridpowersystems.org/crete2019/downloads/

[27] Biza, S., Piromalis, D., Barkas, D., Psomopoulos, C.S., \& Tsikeris, C.D., "Crete-Peloponnese $150 \mathrm{KV}$ AC interconnection. Simulation results for transient phenomena in main switches," Energy Procedia, vol. 157, pp. 1366-1376, 2019. 10.1016/j.egypro.2018.11.301.

[28] Vourdoubas, J., "Creation of Net Zero Carbon Emissions Residential Buildings due to Energy use in the Mediterranean Region: Are they Feasible?," Civil Engineering Research Journal, vol. 10(1), ID 555777, 2020.

[29] Katsaprakakis, D., Antonakakis, I., Dakanali, I., \& Christakis, D., "Turning Crete into an energy independent island", $4^{\text {th }}$ International Hybrid Power Systems workshop, Crete, Greece, 2019. Available: https://www.researchgate.net/publication/333701601_Turning_Crete_ into_an_energy_independent_island.

[30] TILOS - Technology innovation for the local scale, optimum integration of battery energy storage (2015). Retrieved at 4/2/2021 from https://www.tiloshorizon.eu/images/deliverables/TILOSFlyer_EN.pdf.
[31] $\mathrm{CO}_{2}$ emissions (metric tons per capita) - Greece, at https://data. worldbank.org/indicator/EN.ATM.CO2E.PC?locations=G R. 